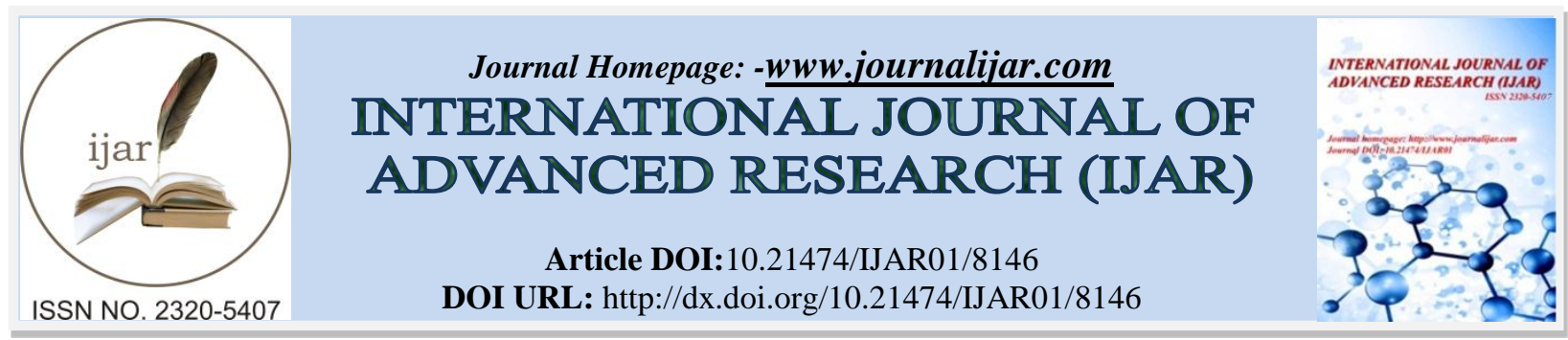

RESEARCH ARTICLE

\title{
EVALUATION OF CHANGES IN BIOCHEMICAL PARAMETERS OF BANANA (MUSA SPP.) STORED IN POLYPROPYLENE PACKAGINGS.
}

\section{Kouame Akissi Françoise ${ }^{1}$, Loa Jean-François Régis Bilo ${ }^{2}$, N'goran Essan Bla Zita ${ }^{3}$ and Tano Kablan ${ }^{3}$.}

1. Laboratory of Food Biochemistry and Technology of Tropical Products, Department of Food Sciences and Technologies, NanguiAbrogoua University, Côte d'Ivoire., 02 BP 801 Abidjan 02, Côte d'Ivoire,

2. Nutrition group and technology alimentary, National institute polytechnic Félix HouphouetBoigny, Yamoussokro, Côte d'Ivoire, BP 1313, Yamoussokro.

\section{Manuscript Info}

Manuscript History

Received: 04 October 2018

Final Accepted: 06 November 2018

Published: December 2018

Keywords:-

plantain, storage, biochemical parameters, polypropylene packaging.

\section{Abstract}

This study was carried out to evaluate the effect of polypropylene packaging on biochemical parameters of plantain. Two varieties of banana (French 2 and Corne 1) harvested at 70 and 75 days after floral apparition have been stored at $25{ }^{\circ} \mathrm{C}$ in 0.235 and $0.303 \mathrm{~mm}$ thick polypropylene (PP) packaged. Biochemical characteristics such as $\mathrm{pH}$, titratable acidity, ripening stage, moisture content, ash, reducing sugars and starch content were determined. The results showed that Polypropylene packaging stabilized the biochemical characteristics of plantain. The result about French 2 indicated stability of parameters between the $12^{\text {th }}$ and $14^{\text {th }}$ day of storage in the bags of $0.235 \mathrm{~mm}$ thickness and $18^{\text {th }}$ and $20^{\text {th }}$ day of storage in the bags of $0.303 \mathrm{~mm}$ thickness. However, for Corne 1 variety, the parameters were stable between $10^{\text {th }}$ and $12^{\text {th }}$ days of storage and $16^{\text {th }}$ and $18^{\text {th }}$ days respectively in packages of thickness 0.235 and $0.303 \mathrm{~mm}$. Significant differences were not observed for the same treatment at maturity levels of $70^{\text {th }}$ and $75^{\text {th }}$ days. The stability time of the physicochemical characteristics of French 2 variety is significantly longer.

Copy Right, IJAR, 2018,. All rights reserved.

\section{Introduction:-}

Plantain is one of the main food resources in Ivory Coast, and it has a high level of local consumption (Lassoudière, 1973). Post harvest losses a major problem limiting the production of plantain and banana in Africa due to unavailability of established storage conditions that canguarantee longer shelf life (Wills, et al., 1989). Annual production of plantain in Ivory Coast is estimated at 1.6 million tons, ranking it third in this country after yam and rice (Ducroquet, 2002; FAO, 2009). During ripening the colour of plantain changes from dark green to bright yellow, due to the degradation of chlorophyll structure, which gradually unmasks the carotenoid pigments present in the fruit (Robinson, 1996). Commercial standard colour charts are available in which 7 stages of ripening were reproduced and translated to a numerical scale where Stage $1=$ green, $2=$ light green, $3=$ more green than yellow, 4 $=$ more yellow than green, $5=$ yellow with extremity green, $6=$ yellow, $7=$ yellow with black spots $($ Tapre and Jain., 2012). In banana, post harvest compositional changes following are important since banana is a climacteric fruit. During the ripening process, there are many biochemical changes, including intense increase in ethylene production, respiration, hydrolysis of starch, increase in sugar content, lower $\mathrm{pH}$ and reduction of organic acids,

Corresponding Author:-Kouame Akissi Francoise. 
pigment synthesis, chlorophyll regression and solubilization of pectic compounds (Grierson et al., 1981, Lizada, 1993).

Modified atmosphere packaging (MAP) of fresh banana refers to the technique of sealing actively respiring banana in polymeric film packages to modify the $\mathrm{O}_{2}$ and $\mathrm{CO}_{2}$ levels within the package atmosphere. It is often desirable to generate an atmosphere low in $\mathrm{O}_{2}$ and/or high in $\mathrm{CO}_{2}$ to influence the metabolism of the product being packaged or the activity of decay-causing organisms to increase storability and/or shelf life (Workneh et al. 2009). In addition to atmosphere modification, MAP vastly improves moisture retention, which can have a greater influence on preserving quality. Further more, packaging isolates the productfrom the external environment and extends the shelf life of the produce (Beaudry, 2000).

Investigations on the use of polypropylene bags for extending the green life of plantain fruits have been carried out (Loa et al., 2017). This study proposes to follow some biochemical parameters of plantain stored with polypropylene packaging.

\section{Material And Methods:}

\section{Plant material:}

In this study two varieties of plantain such Corne 1 and French 2 were used. These plantain varieties harvested at $70^{\text {th }}$ and $75^{\text {th }}$ days after floral apparition were obtained from plantations of Yamoussoukro area $\left(6^{\circ} 49^{\prime} \mathrm{N}\right.$ and $5^{\circ} 16^{\prime}$ O), located in the center of Côte d'Ivoire.

\section{Packages:-}

The fruits were packed in polypropylene (PP) bags of thickness 0.235 and $0.303 \mathrm{~mm}$ due to $10 \mathrm{~kg}$ per bag. The extremity of the bags was firmly closed with a thread.

\section{Storage conditions:-}

Ten (10) $\mathrm{kg}$ of unpackaged bananas served as a control. The whole of packaged and unpackaged bananas were stored at ambient conditions at $25{ }^{\circ} \mathrm{C}$ during 25 days. Every week, a fruit has been removed and subjected to various physicochemical analyzes. The sampling consisted of three batches of plantain.

- Batch 1: control (F70 T, F75 T, C70 T and C75 T)

- Batch 2: fruit packed in PP bags of 0,235 mm thickness (F70 SPI, F75 SPI, C70 SPI and C75 SPI)

- Batch 3: Fruit packed in PP bags of thickness 0.303 mm (F70 SPII, F75 SPII, C70 SPII and C75 SP II).

\section{Biochemical analyzes:-}

The hydrogen potential $(\mathrm{pH})$ of the samples was measured with a $\mathrm{pH}$ - meter (METROM E 520). Titratable acidity was determined by direct titration of diluted pulp with $0.1 \mathrm{~N} \mathrm{NaOH}$ as described by Ranganna (1986). Moisture content was determined by desiccation in a drying oven at $105{ }^{\circ} \mathrm{C}$ during 24 hours (AOAC, 2005). Reducing sugars were determined according to the method of Bernfeld (1955) using 3.5-dinitro-salicylic acids. The ripening stages were determined by the methods of Lii et al. (1982). Proteins contents were measured by Kjeldahl method (AOAC, 2005). Ashes were obtained by calcination in a muffle furnace at $550{ }^{\circ} \mathrm{C}$ during 6 hours (AOAC, 2005). Starch content was determined by the formula of Bertrand and Thomas (1910). All determinations were performed in triplicates.

\section{Statistical analysis:}

The analysis data were processed using STATISTICA 7.0 software. An analysis of variance (ANOVA) with 3 classification criteria (type of cultivar, degree of maturity and type of packaging) was carried out to evaluate the effect of the type of packaging on the biochemical parameters of the two varieties. The Duncan test at the $5 \%$ threshold was used to rank the mean.

\section{Results:}

Evolution of pH and titratable acidity during storage at $25^{\circ} \mathrm{C}$ :

Figure 1 and 2 represents respectively $\mathrm{pH}$ and titratable acidity of fruit pulp of French 2 (A) and Corne 1 (B) varieties harvested at $70^{\text {th }}$ and $75^{\text {th }}$ days, then stored at $25{ }^{\circ} \mathrm{C}$. pH of controls varied significantly from 6.25 to 4.16 and from 6.39 to 4.14 respectively in French 2 and Corne 1 varieties harvested at $70^{\text {th }}$ and $75^{\text {th }}$ days. On the other 
hand, the $\mathrm{pH}$ of both varieties stored with polypropylene bags of thickness 0.235 and $0.303 \mathrm{~mm}$ were stable during $16^{\text {th }}$ and $20^{\text {th }}$ days of storage respectively.

The titratable acidity of the control pulps increased significantly $(\mathrm{p}<0.05)$ in the two varieties harvested at $70^{\text {th }}$ and $75^{\text {th }}$ days. Figure $2 \mathrm{~A}$ and $2 \mathrm{~B}$ showed a stability of titratable acidity during 14 days into fruits packaged in bags of thickness $0.303 \mathrm{~mm}$.
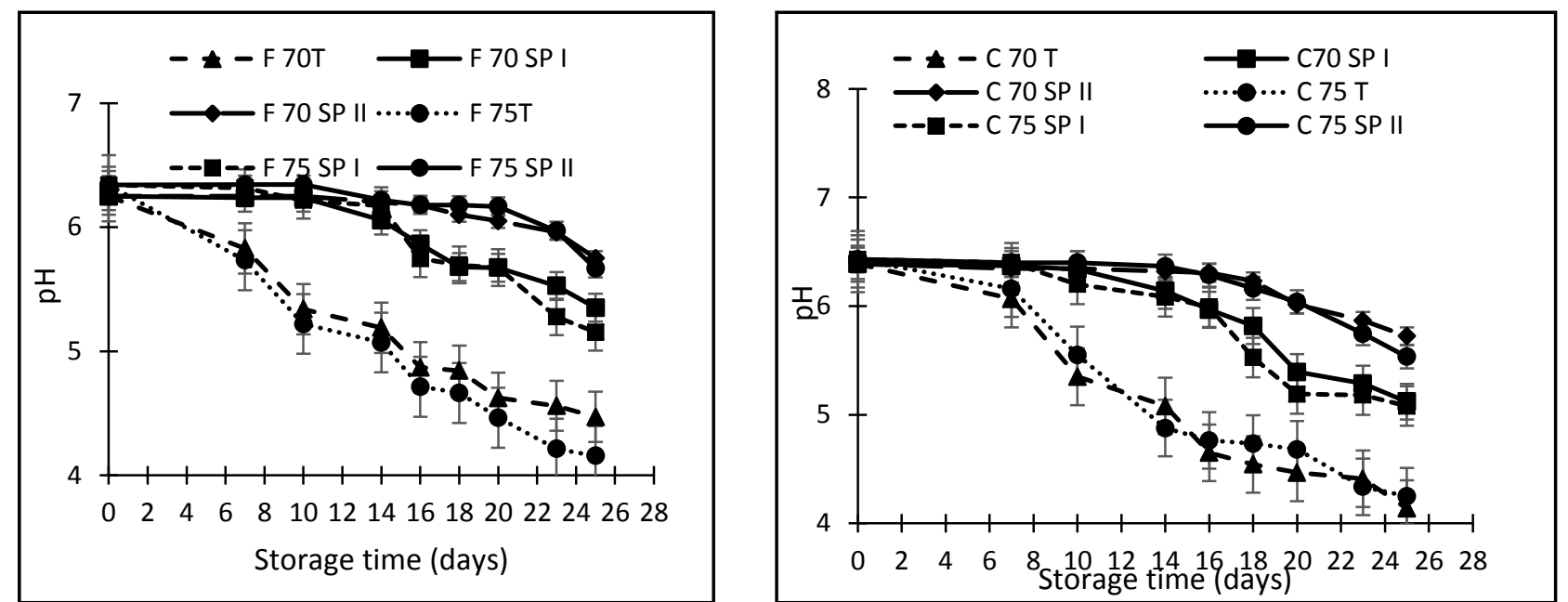

Figure 1: $\mathrm{pH}$ of French 2 (A) and Corne 1 (B) varieties harvested at $70^{\text {th }}$ and $75^{\text {th }}$ days and stored in polypropylene packaging at temperature of $25^{\circ} \mathrm{C}$

F70 T : French 2 Control DM 70, F70 SP I : French 2 DM 70, PP packings (0,235 mm), F70 SP II : French 2 DM 70, PP packing $(0,303 \mathrm{~mm})$, F75 T : French 2 control DM 75, F75 SP II : French 2 DM 75, PP packing (0,235 mm), F75 SP II : French 2 DM 75, PP packing $(0,303 \mathrm{~mm})$. C70 T : Corne 1 control DM 70, C70 SP I : Corne 1 DM 70, PP packing $(0,235 \mathrm{~mm})$, C70 SP II : Corne $1 \mathrm{DM} 70$, PP packing $(0,303 \mathrm{~mm})$, C75 T : Corne 1 control DM 75, C75 SP I : Corne 1 DM 75, PP packing $(0,235 \mathrm{~mm})$, C75 SP II : Corne 1 DM 75, PP packing (0,303 mm).

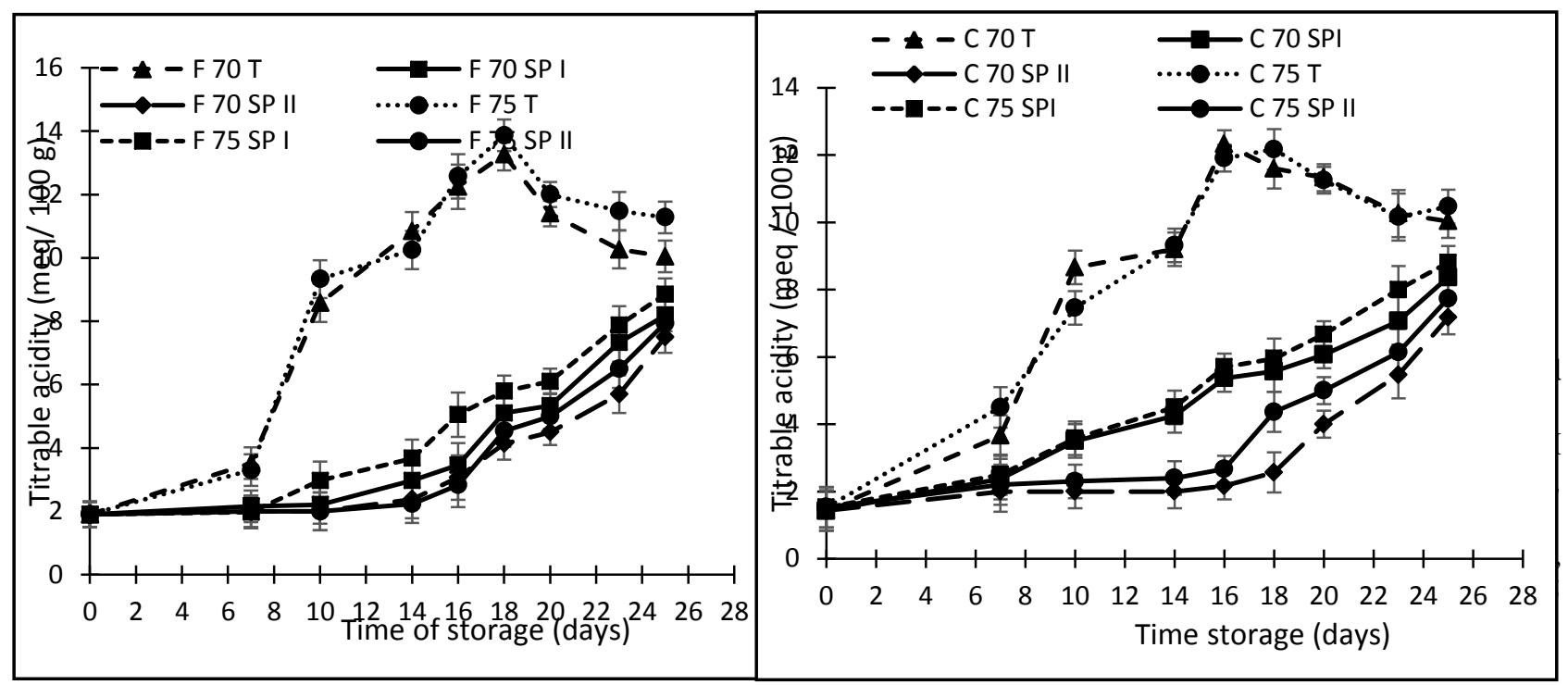

Starch and reducing sugars content:-

Figure 3 and 4 shows the evolution of starch and reducing sugars content of pulp of French 2 and Corne 1 varieties harvested at $70^{\text {th }}$ and $75^{\text {th }}$ days, then stored at $25^{\circ} \mathrm{C}$. 
In control fruits, Starch content varied from 56.41 to $2.31 \%$ and from 59.27 to $2.26 \%$ respectively in fruit pulps of French 2 and Corne 1 varieties. This parameter decreased significantly. Paralely, sugar reducing increased significantly during storage into both varieties control. Into Fruits packaged with polypropylene $(0.303 \mathrm{~mm}$ tickness $)$ the result showed a stability of sarch and reducing sugar during 16 and 18 days of storage into Corne land French 2 respectively. In the $0.235 \mathrm{~mm}$ thick bags, the starch contents of the pulps of both varieties remained stable for $14^{\text {th }}$ days. Regarding reducing sugar, a stability was observed during 12 and 10 days respectively into French 2 and Corne 1.
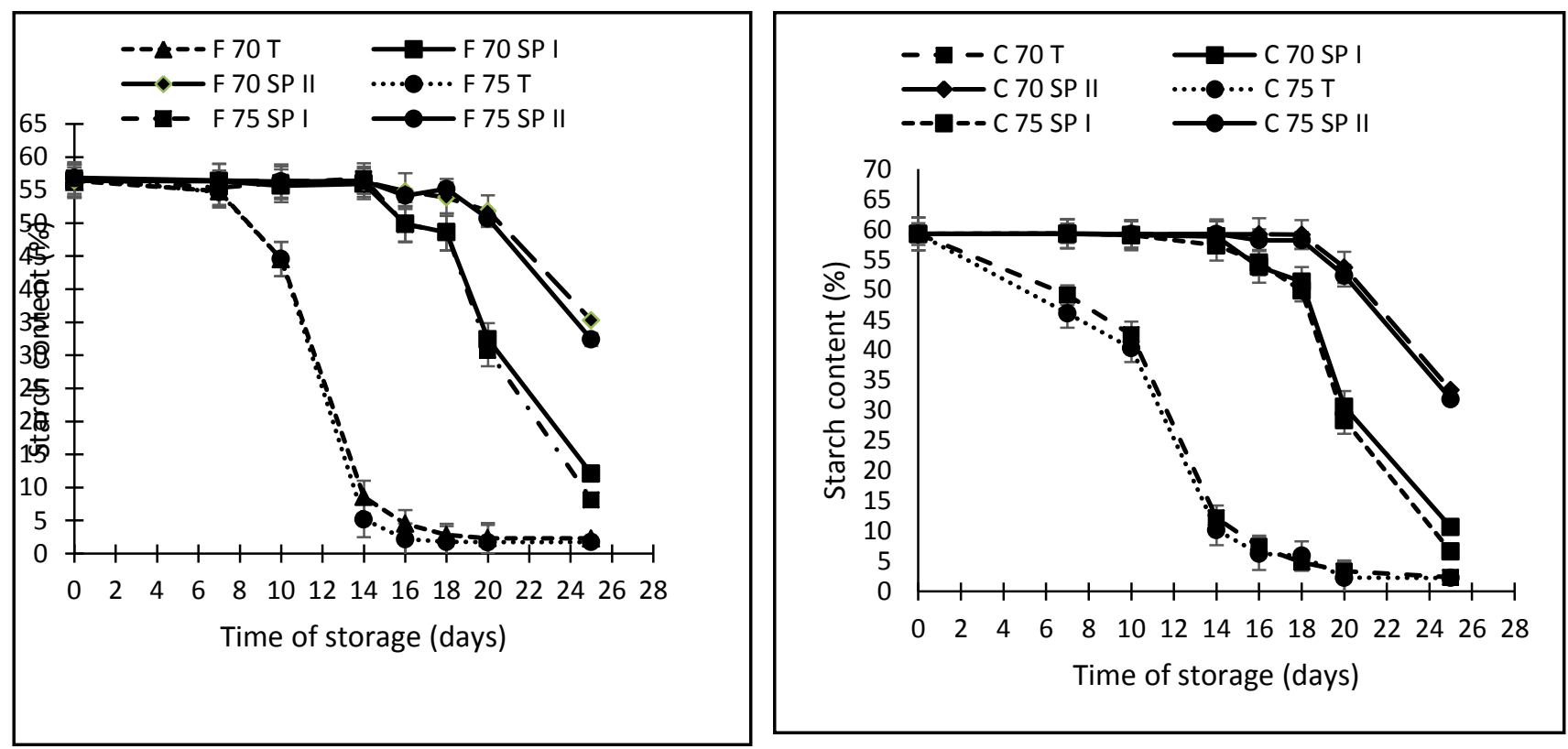

Figure 3:-Evolution of the reducing sugar content of the fruit pulp of the French 2 (A) and Corne 1 (B) varieties harvested at $70^{\text {th }}$ and $75^{\text {th }}$ days and stored in polypropylene packaging at temperature of $25^{\circ} \mathrm{C}$
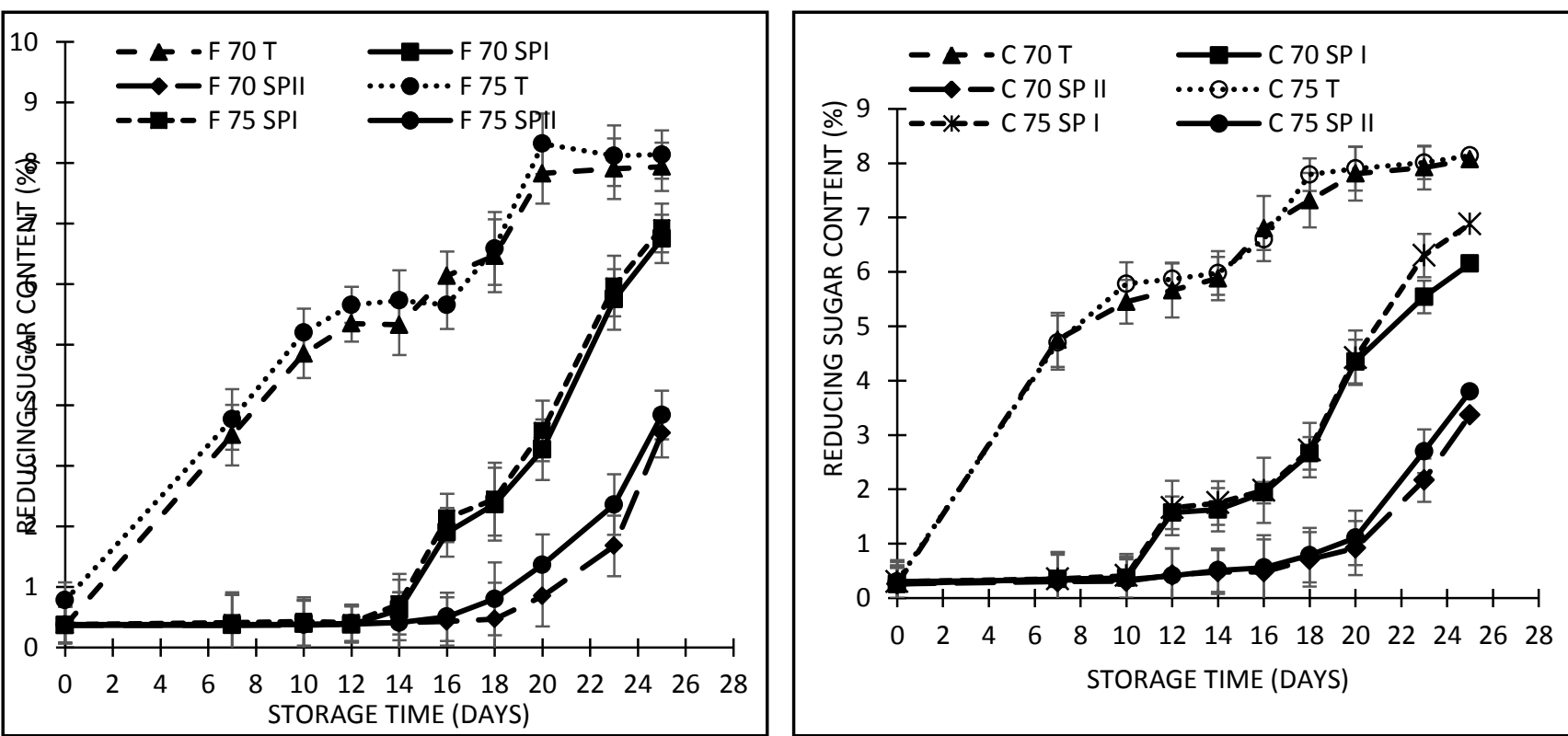

Figure 4:-Evolution of the reducing sugar content of the fruit pulp of the French $2(\mathrm{~A})$ and Corne $1(\mathrm{~B})$ varieties harvested at $70^{\text {th }}$ and $75^{\text {th }}$ days and stored in polypropylene packing at temperature of $25^{\circ} \mathrm{C}$ 
F70 T : French 2 Control DM 70, F70 SP I : French 2 DM 70, PP packings (0,235 mm), F70 SP II : French 2 DM 70, PP packing(0,303 mm), F75 T : French 2 control DM 75, F75 SP II : French 2 DM 75, PP packing (0,235 mm), F75 SP II : French 2 DM 75, PP packing(0,303 mm). C70 T : Corne 1 control DM 70, C70 SP I : Corne 1 DM 70 , PP packing(0,235 mm), C70 SP II : Corne $1 \mathrm{DM} 70$, PP packing(0,303 mm), C75 T : Corne 1 control DM 75, C75 SP I : Corne 1 DM 75, PP packing(0,235 mm), C75 SP II : Corne 1 DM 75, PP packing (0,303 mm).

\section{Ripening stage, moisture, ash and protein content:-}

These parameters were showed into table 1 and table 2 . The results of ripening stages show that the control spend 7 days to pass from green stage at more yellow than green stage, while the more advanced stage such as the yellow with extremity green is observed after 18 and 20 days of storage respectively in packaging in PP of thickness 0,235 and $0,303 \mathrm{~mm}$.

The moisture content was found increased till last day of storage. They ranged from 60.07 to $70.08 \%$ and from 61.64 to $71.79 \%$ with a significant increase observed from the $7^{\text {th }}$ and $25^{\text {th }}$ day respectively in the control pulps of French 2 and Corne 1 varieties. In fruit pulps packed in $0.235 \mathrm{~mm}$ thick bags, moisture content was stable until $14^{\text {th }}$ and $16^{\text {th }}$ days respectively in Corne 1 and French 2 varieties. On the other hand, in packages of thickness $0.303 \mathrm{~mm}$, this stability was observed in the same varieties until $20^{\text {th }}$ days. Beyond these periods of stability, moisture content increased significantly in fruit pulpe packed.

Proteins contents increased significantly $(\mathrm{p}<0.05)$ in the control pulps during storage of French 2 and Corne 1 varieties. On the other hand, the proteins contents remained stables for $16^{\text {th }}$ to $18^{\text {th }}$ days and $20^{\text {th }}$ days in the fruits packaged respectively in the bags of thickness 0.235 and $0.303 \mathrm{~mm}$.

For controls, ash content increased of $1^{\text {st }}$ to $25^{\text {th }}$ days from 1.86 to $3.67 \%$ and from 2.27 to $3.72 \%$ respectively in French 2 and Corne 1 varieties. These parameters were stable for $14^{\text {th }}$ and $20^{\text {th }}$ days respectively in both varieties stored into the bags of thickness 0.235 and $0.303 \mathrm{~mm}$.

Table 1:-Effect of polypropylene packaging on evolution of ripening stage and biochemical characteristics of French 2 variety harvested at $70^{\text {th }}$ and $75^{\text {th }}$ days and stored of $25^{\circ} \mathrm{C}$.

\begin{tabular}{|l|c|c|c|c|c|}
\hline Treatments & $\begin{array}{c}\text { Storage } \\
\text { time (days) }\end{array}$ & Ripening stage & $\begin{array}{c}\text { Moisture } \\
(\%)\end{array}$ & $\begin{array}{c}\text { Ash } \\
(\%)\end{array}$ & $\begin{array}{c}\text { Proteins } \\
(\%)\end{array}$ \\
\hline & 1 & & $60,07 \pm 0,8 \mathrm{a}$ & $0,37 \pm 0,05 \mathrm{a}$ & $3,38 \pm 1,4 \mathrm{a}$ \\
& 7 & More yellow than green & $62,33 \pm 1,3 \mathrm{~b}$ & $0,38 \pm 0,04 \mathrm{a}$ & $3,41 \pm 0,8 \mathrm{a}$ \\
& 14 & Yellow with black spots & $66,21 \pm 0,9 \mathrm{c}$ & $0,7 \pm 0,02 \mathrm{~b}$ & $5,25 \pm 0,5 \mathrm{~b}$ \\
& 18 & All black & $66,73 \pm 1,4 \mathrm{c}$ & $0,73 \pm 0,02 \mathrm{~b}$ & $5,6 \pm 0,2 \mathrm{~b}$ \\
& 20 & All black & $67,51 \pm 0,8 \mathrm{c}$ & $0,71 \pm 0,02 \mathrm{~b}$ & $5,61 \pm 0,2 \mathrm{~b}$ \\
& 25 & All black & $68,94 \pm 1,3 \mathrm{c}$ & $0,76 \pm 0,04 \mathrm{~b}$ & $5,74 \pm 0,6 \mathrm{bc}$ \\
\hline \multirow{4}{*}{ F TPI 70 } & 1 & Green & $60,07 \pm 0,8 \mathrm{a}$ & $0,37 \pm 0,05 \mathrm{a}$ & $3,38 \pm 0,8 \mathrm{a}$ \\
& 7 & More green than yellow & $60,13 \pm 0,5 \mathrm{a}$ & $0,36 \pm 0,01 \mathrm{a}$ & $3,38 \pm 0,8 \mathrm{a}$ \\
& 14 & More green than yellow & $60,72 \pm 1,2 \mathrm{a}$ & $0,37 \pm 0,02 \mathrm{a}$ & $3,41 \pm 0,2 \mathrm{a}$ \\
& 18 & Yellow with extremity green & $63,31 \pm 0,6 \mathrm{~b}$ & $0,45 \pm 0,01 \mathrm{~b}$ & $4,51 \pm 0,2 \mathrm{~b}$ \\
& 20 & Yellow with black spots & $64,66 \pm 1,1 \mathrm{~b}$ & $0,53 \pm 0,02 \mathrm{c}$ & $4,32 \pm 0,2 \mathrm{~b}$ \\
& 25 & All black & $66,55 \pm 0,9 \mathrm{c}$ & $0,73 \pm 0,03 \mathrm{~d}$ & $5,11 \pm 0,6 \mathrm{c}$ \\
\hline \multirow{4}{*}{ F SPII 70 } & 1 & Green & $60,07 \pm 0,8 \mathrm{a}$ & $0,37 \pm 0,05 \mathrm{a}$ & $3,38 \pm 0,8 \mathrm{a}$ \\
& 7 & Green & $60,15 \pm 0,7 \mathrm{a}$ & $0,37 \pm 0,05 \mathrm{a}$ & $3,37 \pm 0,8 \mathrm{a}$ \\
& 14 & Ligth green & $60,73 \pm 1,1 \mathrm{a}$ & $0,36 \pm 0,02 \mathrm{a}$ & $3,41 \pm 0,2 \mathrm{a}$ \\
& 18 & More green than yellow & $60,89 \pm 1,3 \mathrm{a}$ & $0,37 \pm 0,02 \mathrm{a}$ & $3,39 \pm 0,2 \mathrm{a}$ \\
& 20 & Yellow with extremity green & $61,02 \pm 0,6 \mathrm{a}$ & $0,38 \pm 0,02 \mathrm{a}$ & $3,42 \pm 0,2 \mathrm{a}$ \\
& 25 & yellow & $63,41 \pm 0,4 \mathrm{~b}$ & $0,54 \pm 0,04 \mathrm{~b}$ & $4,25 \pm 0,6 \mathrm{~b}$ \\
\hline & 1 & Green & $60,44 \pm 1,3 \mathrm{a}$ & $0,38 \pm 0,01 \mathrm{a}$ & $3,38 \pm 0,7 \mathrm{a}$ \\
& 7 & More green than yellow & $62,75 \pm 0,6 \mathrm{~b}$ & $0,37 \pm 0,04 \mathrm{a}$ & $3,43 \pm 0,6 \mathrm{a}$ \\
& 14 & Yellow & $66,31 \pm 1,1 \mathrm{c}$ & $0,73 \pm 0,02 \mathrm{~b}$ & $5,33 \pm 0,3 \mathrm{~b}$ \\
& 18 & Yellow with black spots & $68,01 \pm 0,7 \mathrm{~d}$ & $0,72 \pm 0,02 \mathrm{~b}$ & $5,53 \pm 0,3 \mathrm{~b}$ \\
& 20 & All black & $69,4 \pm 0,8 \mathrm{~d}$ & $0,76 \pm 0,04 \mathrm{~b}$ & $5,73 \pm 0,3 \mathrm{c}$ \\
& 25 & All black & $70,08 \pm 1,3 \mathrm{~d}$ & $0,77 \pm 0,01 \mathrm{~b}$ & $5,83 \pm 0,3 \mathrm{c}$ \\
\hline & 1 & Green & $60,44 \pm 1,3 \mathrm{a}$ & $0,38 \pm 0,01 \mathrm{a}$ & $3,38 \pm 0,7 \mathrm{a}$ \\
\hline
\end{tabular}




\begin{tabular}{|l|c|c|c|c|c|}
\hline \multirow{3}{*}{ F SPI 75 } & 7 & More green than yellow & $60,34 \pm 0,8 \mathrm{a}$ & $0,38 \pm 0,01 \mathrm{a}$ & $3,39 \pm 0,8 \mathrm{a}$ \\
& 14 & More green than yellow & $60,82 \pm 1,1 \mathrm{a}$ & $0,37 \pm 0,01 \mathrm{a}$ & $3,52 \pm 0,2 \mathrm{a}$ \\
& 18 & Yellow & $63,5 \pm 0,6 \mathrm{~b}$ & $0,51 \pm 0,01 \mathrm{c}$ & $4,36 \pm 0,2 \mathrm{~b}$ \\
& 20 & Yellow with black spots & $64,83 \pm 0,7 \mathrm{~b}$ & $0,56 \pm 0,02 \mathrm{c}$ & $4,74 \pm 0,2 \mathrm{~b}$ \\
& 25 & All black & $66,95 \pm 1,2 \mathrm{c}$ & $0,74 \pm 0,03 \mathrm{~d}$ & $5,16 \pm 0,6 \mathrm{c}$ \\
\hline & 1 & Green & $60,44 \pm 1,3 \mathrm{a}$ & $0,38 \pm 0,01 \mathrm{a}$ & $3,38 \pm 0,7 \mathrm{a}$ \\
& 7 & Green & $60,71 \pm 0,8 \mathrm{a}$ & $0,37 \pm 0,01 \mathrm{a}$ & $3,37 \pm 0,8 \mathrm{a}$ \\
& 14 & Ligth green & $60,97 \pm 0,3 \mathrm{a}$ & $0,38 \pm 0,01 \mathrm{a}$ & $3,38 \pm 0,2 \mathrm{a}$ \\
& 18 & More green than yellow & $61,43 \pm 1,1 \mathrm{a}$ & $0,37 \pm 0,02 \mathrm{a}$ & $3,45 \pm 0,2 \mathrm{a}$ \\
& 20 & More yellow than green & $61,32 \pm 0,9 \mathrm{a}$ & $0,38 \pm 0,02 \mathrm{a}$ & $3,45 \pm 0,2 \mathrm{a}$ \\
& 25 & Yellow & $64,7 \pm 0,6 \mathrm{~b}$ & $0,55 \pm 0,03 \mathrm{~b}$ & $4,48 \pm 0,6 \mathrm{~b}$ \\
\hline
\end{tabular}

Data on the same column with different miniscule letters are significantly different ( $\leq 0.05$ ). FT70 : Var. French 2 control DM 70, FSPI 70 :Var. French 2DM 70 PP packings $(0,235 \mathrm{~mm})$, FSPII 70 Var. French 2 DM 70 PP packings $(0,303 \mathrm{~mm})$, FT75 : Var. French 2 control DM 75, FSPI 75 :Var. French 2DM 75 PP packings $(0,235$ $\mathrm{mm})$, FSPII 75 : Var. French 2DM 7 PP packings $(0,303 \mathrm{~mm})$.

Table 2 : Effect of polypropylene packaging on evolution of ripening stage and biochemical characteristics of Corne 1 variety harvested at $70^{\text {th }}$ and $75^{\text {th }}$ days and stored of $25^{\circ} \mathrm{C}$.

\begin{tabular}{|c|c|c|c|c|c|}
\hline Treatments & $\begin{array}{c}\text { Storage } \\
\text { time (days) }\end{array}$ & Stage of ripening & $\begin{array}{c}\text { Moisture } \\
\%\end{array}$ & $\begin{array}{c}\text { Ash } \\
\%\end{array}$ & $\begin{array}{c}\text { Proteins } \\
\%\end{array}$ \\
\hline C T 70 & $\begin{array}{c}1 \\
7 \\
14 \\
18 \\
20 \\
25\end{array}$ & $\begin{array}{c}\text { Green } \\
\text { More yellow than green } \\
\text { Yellow with black spots } \\
\text { All black } \\
\text { All black } \\
\text { All black }\end{array}$ & $\begin{array}{l}61,5 \pm 0,5 \mathrm{a} \\
63,56 \pm 0,7 \mathrm{~b} \\
66,33 \pm 1,1 \mathrm{c} \\
69,33 \pm 0,5 \mathrm{~d} \\
69,98 \pm 0,4 \mathrm{~d} \\
70,15 \pm 0,2 \mathrm{~d}\end{array}$ & $\begin{array}{l}0,4 \pm 0,05 \mathrm{a} \\
0,58 \pm 0,03 \mathrm{~b} \\
0,73 \pm 0,02 \mathrm{c} \\
0,76 \pm 0,02 \mathrm{c} \\
0,76 \pm 0,14 \mathrm{c} \\
0,75 \pm 0,01 \mathrm{c}\end{array}$ & $\begin{array}{l}4,16 \pm 0,6 \mathrm{a} \\
4,48 \pm 0,4 \mathrm{a} \\
5,86 \pm 0,6 \mathrm{~b} \\
5,88 \pm 0,6 \mathrm{~b} \\
5,91 \pm 0,3 \mathrm{~b} \\
5,91 \pm 0,7 \mathrm{~b}\end{array}$ \\
\hline C SPI 70 & $\begin{array}{c}1 \\
7 \\
14 \\
18 \\
20 \\
25\end{array}$ & $\begin{array}{c}\text { Green } \\
\text { More green than yellow } \\
\text { More green than yellow } \\
\text { Yellow } \\
\text { Yellow with black spots } \\
\text { All black } \\
\end{array}$ & $\begin{array}{l}61,5 \pm 0,5 \mathrm{a} \\
61,53 \pm 0,5 \mathrm{a} \\
61,96 \pm 1,1 \mathrm{a} \\
65,32 \pm 0,7 \mathrm{~b} \\
65,63 \pm 0,3 \mathrm{~b} \\
67,87 \pm 1,1 \mathrm{c} \\
\end{array}$ & $\begin{array}{c}0,4 \pm 0,05 \mathrm{a} \\
0,43 \pm 0,02 \mathrm{a} \\
0,55 \pm 0,01 \mathrm{~b} \\
0,52 \pm 0,01 \mathrm{~b} \\
0,56 \pm 0,42 \mathrm{~b} \\
0,71 \pm 0,03 \mathrm{c}\end{array}$ & $\begin{array}{l}4,16 \pm 0,6 \mathrm{a} \\
4,18 \pm 0,3 \mathrm{a} \\
4,57 \pm 0,2 \mathrm{a} \\
4,53 \pm 0,2 \mathrm{a} \\
5,29 \pm 0,1 \mathrm{~b} \\
5,73 \pm 0,4 \mathrm{~d}\end{array}$ \\
\hline C SPII 70 & $\begin{array}{c}1 \\
7 \\
14 \\
18 \\
20 \\
25\end{array}$ & $\begin{array}{c}\text { Green } \\
\text { Green } \\
\text { More green than yellow } \\
\text { More green than yellow } \\
\text { More yellow than green } \\
\text { Yellow }\end{array}$ & $\begin{array}{l}61,5 \pm 0,5 \mathrm{a} \\
61,52 \pm 0,7 \mathrm{a} \\
61,57 \pm 0,3 \mathrm{a} \\
61,75 \pm 0,6 \mathrm{a} \\
61,94 \pm 0,6 \mathrm{a} \\
64,59 \pm 0,1 \mathrm{~b}\end{array}$ & $\begin{array}{c}0,4 \pm 0,05 \mathrm{a} \\
0,41 \pm 0,05 \mathrm{a} \\
0,43 \pm 0,02 \mathrm{a} \\
0,43 \pm 0,02 \mathrm{a} \\
0,51 \pm 0,22 \mathrm{~b} \\
0,55 \pm 0,04 \mathrm{~b}\end{array}$ & $\begin{array}{l}4,16 \pm 0,6 \mathrm{a} \\
4,17 \pm 0,9 \mathrm{a} \\
4,16 \pm 0,5 \mathrm{a} \\
4,19 \pm 0,5 \mathrm{a} \\
4,48 \pm 0,3 \mathrm{a} \\
5,12 \pm 0,7 \mathrm{~b}\end{array}$ \\
\hline C T 75 & $\begin{array}{c}1 \\
7 \\
14 \\
18 \\
20 \\
25\end{array}$ & $\begin{array}{c}\text { Green } \\
\text { Yellow } \\
\text { Yellow with black spots } \\
\text { All black } \\
\text { All black } \\
\text { All black }\end{array}$ & $\begin{array}{l}61,64 \pm 0,8 \mathrm{a} \\
63,69 \pm 0,4 \mathrm{~b} \\
66,56 \pm 1,1 \mathrm{c} \\
68,86 \pm 0,8 \mathrm{~d} \\
70,53 \pm 0,7 \mathrm{e} \\
70,79 \pm 1,1 \mathrm{e}\end{array}$ & $\begin{array}{l}0,4 \pm 0,05 \mathrm{a} \\
0,55 \pm 0,04 \mathrm{~b} \\
0,70 \pm 0,02 \mathrm{c} \\
0,72 \pm 0,02 \mathrm{c} \\
0,76 \pm 0,04 \mathrm{c} \\
0,76 \pm 0,01 \mathrm{c}\end{array}$ & $\begin{array}{c}4,15 \pm 0,5 \mathrm{a} \\
4,57 \pm 0,1 \mathrm{a} \\
5,73 \pm 0,8 \mathrm{~b} \\
5,83 \pm 0,8 \mathrm{~b} \\
5,87 \pm 1,1 \mathrm{~b} \\
5,93 \pm 0,9 \mathrm{bc}\end{array}$ \\
\hline C SPI 75 & $\begin{array}{c}1 \\
7 \\
14 \\
18 \\
20 \\
25\end{array}$ & $\begin{array}{c}\text { Green } \\
\text { More green than yellow } \\
\text { More green than yellow } \\
\text { Yellow } \\
\text { Yellow with black spots } \\
\text { All black }\end{array}$ & $\begin{array}{l}61,64 \pm 0,8 \mathrm{a} \\
61,62 \pm 0,7 \mathrm{a} \\
61,74 \pm 0,4 \mathrm{a} \\
65,72 \pm 1,3 \mathrm{~b} \\
67,18 \pm 0,6 \mathrm{c} \\
67,97 \pm 0,6 \mathrm{c}\end{array}$ & $\begin{array}{c}0,4 \pm 0,05 \mathrm{a} \\
0,4 \pm 0,01 \mathrm{a} \\
0,51 \pm 0,01 \mathrm{~b} \\
0,53 \pm 0,01 \mathrm{~b} \\
0,57 \pm 0,02 \mathrm{~b} \\
0,71 \pm 0,03 \mathrm{c}\end{array}$ & $\begin{array}{l}4,5 \pm 0,5 \mathrm{a} \\
4,6 \pm 0,7 \mathrm{a} \\
4,58 \pm 0,2 \mathrm{a} \\
4,57 \pm 0,2 \mathrm{a} \\
5,35 \pm 0,1 \mathrm{~b} \\
5,71 \pm 0,7 \mathrm{~b}\end{array}$ \\
\hline C SPII 75 & $\begin{array}{c}1 \\
7 \\
14 \\
18 \\
20 \\
25\end{array}$ & $\begin{array}{c}\text { Green } \\
\text { Green } \\
\text { More green than yellow } \\
\text { More green than yellow } \\
\text { More green than yellow } \\
\text { Yellow }\end{array}$ & $\begin{array}{c}61,64 \pm 0,8 \mathrm{a} \\
61,67 \pm 0,5 \mathrm{a} \\
61,9 \pm 0,2 \mathrm{a} \\
62,28 \pm 0,8 \mathrm{a} \\
62,27 \pm 0,4 \mathrm{a} \\
64,96 \pm 0,5 \mathrm{~b}\end{array}$ & $\begin{array}{c}0,4 \pm 0,05 \mathrm{a} \\
0,41 \pm 0,05 \mathrm{a} \\
0,43 \pm 0,02 \mathrm{a} \\
0,44 \pm 0,02 \mathrm{a} \\
0,52 \pm 0,02 \mathrm{~b} \\
0,55 \pm 0,04 \mathrm{~b}\end{array}$ & $\begin{array}{l}4,15 \pm 0,5 \mathrm{a} \\
4,22 \pm 0,3 \mathrm{a} \\
4,25 \pm 0,6 \mathrm{a} \\
4,25 \pm 0,6 \mathrm{a} \\
4,47 \pm 0,5 \mathrm{a} \\
5,12 \pm 0,2 \mathrm{~b}\end{array}$ \\
\hline
\end{tabular}


Data on the same column with different miniscule letters are significantly different $(\mathrm{p} \leq 0.05)$. CT70 : Var.Corne 1control DM 70, CSPI 70 :Var. Corne 1DM 70 PP packings (0,235 mm), CSPII 70 Var. Corne 1 DM 70 PP packings (0,303 mm), CT75 : Var.Corne 1control DM 75, CSPI 75 :Var. Corne 1DM 75 PP packings (0,235 mm), CSPII 75 : Var. Corne 1DM 7 PP packings $(0,303 \mathrm{~mm})$.

\section{Discussion:-}

The study of the evolution of the biochemical characteristics of French 2 and Corne 1 varieties showed significant variations between the unpackaged control samples and the fruits packed in the polypropylene bags. In general, there is a significant change in biochemical characteristics in unpackaged fruit from the $7^{\text {th }}$ day of storage.

The $\mathrm{pH}$ of fruit decreases significantly during storage. Similar results have been reported by Assemand et al., (2012). The gradual decline in fruit $\mathrm{pH}$ during maturation or storage was attributed to an accumulation of acidic organic materials, such as malic acid, which are generally associated with maturation (Wyman and Palmer, 1964).

The increase in pulp moisture content during ripening may be due to carbohydrate breakdown and osmotic transfer from the peel to pulp due to its high sugar concentration (Izonfuoand Omuaru 1998, John and Marchal1995).

During maturation, starch decreased considerably from green to yellow. Simultaneously, the soluble sugar content increased in pulp of plantains. This synchronism can be explained by the degradation of the starch and the formation of free sugars under the action of the enzymes. Thus, during ripening, plantain starch is hydrolysed by enzymes such as $\alpha$-amylase (Purgatto et al. 2001; Do Nascimento et al., 2006).

Starch degradation was slower into the pulp packaged. The same result was reported by Salunkhe and Kadam (1995). About these authors banana fruits packaged in polyethylene bag were found to have slower enzymatic activity there by the process of starch degradation was slower than open air kept banana fruits.

The appearance of the stages of ripening is longer in the packed fruits (14 to 18 days) that in the control. Similar results were reported by Dongo et al. (2011). Indeed during ripening the loss of the green color of the pericarp of banana is due to the degradation of chlorophyl, which leaves appear the pigments carotenoides (yellow color). This phenomenon would be delayed in the bags in PP because of the low $\mathrm{O}_{2}$ contents at the interior of pack (Lepengue et al., 2010; Yao et al., 2014).

The results showed an increase of protein and ash contents during storage. With respect to proteins, it has been attributed to possible enzyme conversion and / or protein synthesis during ripening (Tressel et al., 1975). Similarly, the increase of ash content has been reported by several authors (Nimsung et al., 2007, Ayo-Omogie et al., 2010). However, the increase of protein and ash content is faster in control fruits and slow in fruit packed in polypropylene bags. Indeed, the high level of $\mathrm{CO}_{2}$ in the conservation medium would slow down the decomposition and synthesis phenomena associated with the ripening of plantain.

The use of polypropylene packaging stabilized plantains parameters up to $14^{\text {th }}$ and $20^{\text {th }}$ days. Similar results were obtained by Yao et al., (2014) and Dongo et al., (2011). The small variations in physicochemical characteristics observed in fruit packed in polypropylene bags could be explained by the presence of $\mathrm{CO}_{2}$ in these bags. This gas is known for its inhibitory action on the enzymes of the respiratory chain, and especially for its opposition to the action of ethylene, phytohormone stimulating fruit ripening. Authors such as Chamara and al. (2000) and Dupin (1992) have shown in their studies that $\mathrm{CO}_{2}$ would inhibit the activity of enzymes in the starch degradation chain. All these physiological actions lead to a slowing of the metabolism, thus prolonging the shelf life and stabilizing the physicochemical characteristics of the fruits during storage (Varoquaux et al., 2002). The shelf-life of PP packages with a thickness of $0.303 \mathrm{~mm}$ is significantly ( $\mathrm{p}<0.05$ ) longer than in packages with a thickness of $0.235 \mathrm{~mm}$. Similar results were obtained by Yao et al., (2014). According to these authors, the permeability of the sachets is, in general, inversely proportional to their thickness. The amount of $\mathrm{CO}_{2}$ accumulated will therefore be higher in polypropylene bags of thickness $0.303 \mathrm{~mm}$ than those of $0.235 \mathrm{~mm}$. 


\section{Conclusion:-}

Modified atmosphere created by the polypropylene bags stabilized biochemical lparameters like $\mathrm{pH}$, titratable acidity, starch ans sugar content, ash, moisture and protein content. These parameters were generaly stable until $14^{\text {th }}$ to $18^{\text {th }}$ into Corne 1 and French 2 respectively. However, polypropylene bags $0.303 \mathrm{~mm}$ thick produced better results than polypropylene bags with $0.235 \mathrm{~mm}$ thick. Significant differences were not observed for the same treatment at maturity levels of $70^{\text {th }}$ and $75^{\text {th }}$ days. The stability time of the biochemical characteristics of French 2 variety was significantly longer.

\section{References Bibliographiques:-}

1. AOAC. (2005). Officiel Method of Analysis. Association of Agricultural Chemist, Washington D.C. 34p.

2. Assemand E., Camara F., Kouamé F., Konan V. \&Kouamé P. (2012). Caractérisation biochimique des fruits de plantain (Musa paradisiaca L.) variété «Agnrin» de Côte d'Ivoire et évaluation sensorielle de ses produits dérivés. Journal of Applied Biosciences, $60: 4438-4447$.

3. Ayo-Omogie H. N., Adeyemi I. A., Ezekiel T. \&Otunola E. T. (2010). Effect of ripening on somephysicochemicalproperties of cooking banana (Musa ABB Cardaba) pulp and flour. International Journal of Food Science and Technology, $45: 2605-2611$.

4. Bernfeld P. (1955). Alpha and beta-amylases. In, Methods in Enzymology, Colowick S.P. et Kaplan N., eds. AcademicPress, New York, 1, 149-158.

5. Beaudry R.M. (2000).Responses of horticultural commodities to lowoxygen: limits to the expanded use of modifiedatmosphere packaging. HortTechnology 10:491-500.

6. Bertrand G et Thomas P. (1910). Guide pour lesmanipulationsde chimiebiologie. Dunod, Paris.

7. Chamara D, Illeperuma K, ThejaGalappatty P, Sarananda KH. (2000). Modifiedatmosphere packaging of 'Kolikuttu' bananas at lowtemperature. Journal of Horticultural Science and Biotechnology, 75(1): 92-96.

8. Dongo R K, Dick E, Fatogoma S, Camara B and Kone D. (2011). Preservingtreatments of physicochemicalproperties of the plantain stored at an ambient temperature. Agric. Biol. J. N. Am. 2(5): 761 766.

9. Do Nascimento J.R.O., Cordenunsi B.R., Lajolo F.M. (2006). Beta-amylase expression and starch degradation during banana ripening. PostharvestBiol. Technol., 40, 41-47.

10. Du croquet H.(2002). L'agriculture Ivoirienne à la loupe (1). Le professionnel agricole. $3: 10-12$.

11. Dupin H. (1992). Alimentation et Nutrition Humaines. Edition ESF : Paris, France; 1533 p.

12. FAO Agricultural statistics. (2009). Food and agriculture organization of the United Nations, Rome.

13. Grierson D., Tucker G. A. \& Robertson N. G. (1981). The molecular biology of ripening. In: Friend J. \& Rhodes M.J.C., ed. Recent advances in the biochemistry of fruits and vegetables. London: Academic Press, 149-160

14. Izonfuo W.L., \& Omuaru V.O.T. (1998). Effect of ripening on the chemical composition of plantain peels and pulps (Musa paradisiaca). J. Sci. Food and Agri.,45, 333-336.

15. John P, Marchal J. (1995).Ripening and biochemistry of the fruit. In: Gowen S (ed) Banana and plantains. Chapman and Hall, London, pp 434-467.

16. Lassoudière A. (1973). Le bananier plantain en Côte d'Ivoire. Fruits. 28(6): 453-462.

17. Lépengué A N, Mouaragadja I, Dick E. (2010). Amélioration de la durée de conservation des bananes plantain aux températures ambiantes. International Journal Biologie ChemiscalSciences 4 (3), 730-737 pp.

18. Lii C. Y., Chang S. M., \& Young Y. L. (1982). Investigation of the physical and chemicalproperties of banana starches. Journal of Food Science, 47 : 1493-1497.

19. Loa J.F., Kouamé A.F., Konan B.R, and TanoK.(2017). Effet des emballages en polypropylène sur la durée de conservation de deux cultivars(French et Corne) de banane plantain (Musa paradisiaca). International Journal of Innovation and AppliedStudies. 19 (3) 699-707.

20. Nimsung P., Thongngam M. \&Naivikul O. (2007). Compositions, morphological and thermal properties of green banana flour and starch. Kasetsart Journal (Nat. Sci.), $41: 324-330$.

21. Purgatto E., Lajolo F.M., Do Nascimento O.J.R., Cordenunsi B.R.(2001). Inhibition of $\alpha$-amylase activity, starchdegradation and sucrose formation by indole-3-acetic acidduring banana ripening. Planta, 212, 823-828.

22. Ranganna S. (1986).Handbook of analysis and quality control for fruits and vegetables, 2nd edn. McGraw Hill, New Delhi.

23. Robinso, J. C. (1996). Distribution and importance; taxonomic classification, cultivars and breeding. In : J. C. Robinson (Ed.), Banana and plantains (p. 1-33). Wallingford: CAB International. 
24. Salunkhe D.K., Kadam S.S. (1995). Banana. In : Hand book of fruit science and technology. Marcel Dekker Inc., New York pp. 67-90.

25. TapreA.R.and Jain R.K. (2012). Study of advancedmaturity stages of banana. International Journal of Advanced Engineering Research and Studies. 1(3), 272-274

26. Tressel R., Holzer M. \&Apertz M. (1975). Biosynthesis of volatile compounds. In :Proceeding of the International Symposium on AromaResearchHeld by the Central Institute for Nutrition and Research. (Edited by P.J. Marsett). 41-62.

27. Varoquaux P, Gouble B, Ducamp MN, Self G. (2002). Méthodepermettantd'optimiser l'emballage des fruits sous atmosphère modifiée. Fruits, 57(5-6): 313-322.

28. Wills, R. H. H., McGlasson, W. B., Graham, D., Lee, T. H. \& Hall, E. G. (1989). Postharvest: An introduction to the physiology and handling of fruit and vegetables. 3rd edition. Blackwell Scientific Publications, Oxford, UK. $176 \mathrm{pp}$.

29. Workneh TS, Osthoff G, Steyn MS. (2009). Integrated agro-technologywithpreharvestComCat ${ }^{\circledR}$ treatment, modifiedatmosphere packaging and forced ventilation evaporativecooling of tomatoes. Afr $\mathrm{J}$ Biotechnol 8(5):860-872.

30. Wyman H, Palmer JK. (1964).Organicacids in the ripening banana fruit. Plant physiology;39(4):630

31. Yao A.K, Koffi D M, Irié Z. B.\&Niamké S. L.(2014). Conservation de la banane plantain (Musa AAB) à l'état vert par l'utilisation de films de polyéthylène de différentes épaisseurs. Journal of Animal \& Plant Sciences. Vol.23, Issue 3: 3677-3690. 